\title{
EFISIENSI PENGGUNAAN PAKAN HIJAUAN PADA USAHA TERNAK SAPI POTONG DI KABUPATEN BANJARNEGARA
}

\author{
Sri Mastuti, Yusmi Nur Wakhidati dan Oentoeng Edy Djatmiko \\ Fakultas Peternakan UNSOED
}

\begin{abstract}
ABSTRAK
Penelitian ini bertujuan untuk: 1) Mengetahui pengaruh penggunaan biaya input pakan hijauan dan input obat dan vitamin terhadap kenaikan nilai produksi sapi potong di Kabupaten Banjarnegara; 2). Mengetahui efisiensi penggunaan biaya hijauan pakan terhadap kenaikan nilai produksi pada usaha ternak sapi potong di Kabupaten Banjarnegara. Penelitian dilaksanakan dengan menggunakan metode survei (Survey Method) terhadap peternak sapi potong. Sampel wilayah dipilih secara stratified random sampling berdasarkan populasi sapi potong, sehingga terpilih 5 kecamatan dari 20 kecamatan yang ada di Kabupaten Banjarnegara yaitu Kecamatan Rakit, Susukan, Pagentan, Purwanegara dan Wanayasa. Selanjutnya sampel peternak dipilih dengan metode Quota Sampling sebanyak 20 peternak dari masing-masing kecamatan terpilih, sehingga terambil 100 responden. Analisis fungsi Cobb- Douglas digunakan untuk melihat pengaruh biaya input terhadap kanaikan nilai produksi, sedangkan efisiensi ekonomi dianalisis dengan membandingkan Nilai Produk Marginal (NPM) dengan Biaya Korbanan Marginal (BKM). Biaya input dikatakan efisien jika nilainya $=1$, belum efisien $>1$, dan tidak efisien $<1$. Hasil penelitian menunjukkan bahwa rata-rata NPM peternak sebesar Rp. 5·350.000,00. BKM pakan hijauan sebesar Rp 2. 028.487,50 dan obat dan vitamin sebesar Rp 201.800,00. Biaya pengadaan input pakan hijauan berpengaruh terhadap kenaikan nilai produksi dengan koefisien sebesar $0,77(\mathrm{P}<0.05)$, sedangkan biaya vitamin dan obat tidak berpengaruh secara signifikan dengan R2 sebesar 0,76. Efisiensi penggunaan biaya pakan hijauan sebesar 2,024 yang berarti penggunaan pakan oleh peternak belum efisien. Demikian pula penggunaan input obat dan vitamin, belum efisien dengan nilai sebesar 1,832. Kenaikan nilai produksi sapi potong di Kabupaten Banjarnegara dapat ditingkatkan dengan meningkatkan efisiensi penggunaan biaya pakan.
\end{abstract}

\section{Kata kunci: efisiensi penggunaan biaya input, usaha ternak sapi potong}

\section{PENDAHULUAN}

Pembangunan di subsektor peternakan antara lain bertujuan untuk meningkatkan konsumsi protein hewani asal ternak, meningkatkan pendapatan, memperluas kesempatan kerja dan lapangan kerja serta diharapkan dapat memberikan sumbangan terhadap devisa daerah setempat. Ternak sapi merupakan salah satu komoditas yang memiliki potensi cukup besar sebagai ternak penghasil daging dan menjadi prioritas dalam pembangunan peternakan. Sapi potong merupakan salah satu sumber daya penghasil bahan makanan berupa daging yang memiliki nilai ekonomis tinggi dan penting artinya di dalam kehidupan masyarakat. Disamping berperan sebagai penghasil daging, sapi potong juga berperan sebagai sumber pendapatan, sarana investasi, tabungan, fungsi sosial, sumber pupuk, sumber tenaga kerja dalam pengolahan tanah dan pemanfaat limbah pertanian (Tumewu dkk., 2014).

Kabupaten Banjarnegara merupakan salah satu sentra produksi dan pengembangan ternak sapi potong berdasarkan potensi alam dan budaya tani yang dimiliki masyarakat. Berdasarkan data dari
Badan Pusat Statistik Kabupaten Banjarnegara (2013), populasi sapi potong dari tahun 2008 sampai 2013 berturut-turut adalah 40.426 ekor, 41.638 ekor, 41.842 ekor, 34.320 ekor, 37.067 ekor dan pada tahun 2013 populasi sapi potong sebanyak 32.222 ekor. Lokasi penyebaran sapi potong terdapat di seluruh Kecamatan di Kabupaten Banjarnegara. Proses penyebaran tersebut didukung oleh luasnya lahan penghasil hijauan makanan ternak (HMT) seluas $21.782 \mathrm{~m} 2$ (BPS, 2013)

Usaha ternak sapi potong dikatakan berhasil jika produksi yang dihasilkan optimal. Sedangkan produksi dikatakan optimal jika penggunaan faktor produksi dilakukan seefisien mungkin. Pada umumnya usaha ternak sapi potong di Indonesia masih dijalankan dengan cara tradisional dengan ciri merupakan usaha sampingan, skala pemeliharaan kecil dan produktivitas yang rendah. Menurut Kalangi (1014), produktivitas ternak dapat ditingkatkan dengan memperbaiki efisiensi usaha secara berkesinambungan. Secara teoritis, produksi daging merupakan hasil interaksi antara faktor endogen dan eksogen. Faktor endogen, sebagai faktor kemampuan biologis, baru dapat ditampilkan jika faktor eksogen 
sebagai faktor kesempatan, memungkinkan faktor endogen berkembang. Tidak kalah penting adalah faktor eksogen. Faktor ini sering disebut dengan faktor lingkungan terdiri atas tiga faktor yaitu iklim, ketersedian pakan dan manajemen pemeliharaan. Kemampuan manajerial peternak yang beragam seringkali mengakibatkan penggunaan input produksi tidak efisien sehingga menyebabkan produksi menjadi tidak optimum. Di sisi lain, kabupaten Banjarnegara memiliki potensi lahan hijauan pakan yang cukup menjanjikan. Besarnya potensi sumber ketersediaan pakan seperti limbah pertanian dan luasnya lahan penghasil hijauan makanan ternak dapat menjadi faktor pendukung bagi pengembangan usaha. Penelitian ini diharapkan dapat memberikan informasi terkait penggunaan faktor produksi khususnya pakan hijauan dalam usaha ternak sapi potong. Selanjutnya akan teridentifikasi tingkat efisiensi penggunaan biaya pakan hijauan pada usaha ternak sapi potong di Kabupaten Banjarnegara.

\section{METODE PENELITIAN}

\section{Metode Pengambilan Sampel}

Penelitian dilaksanakan dengan menggunakan metode survei (Survey Method) terhadap rumah tangga peternak sapi potong. Sampel wilayah dipilih secara stratified random sampling berdasarkan populasi sapi potong, sehingga terpilih 5 kecamatan dari 20 kecamatan yang ada di Kabupaten Banjarnegara yaitu Kecamatan Rakit, Susukan, Pagentan, Purwanegara dan Wanayasa. Selanjutnya sampel peternak dipilih dengan metode Quota Sampling sebanyak 20 peternak dari masing-masing kecamatan terpilih, sehingga terambil 100 responden.

\section{Metode Analisis}

a. Pengaruh penggunaan biaya input terhadap kenaikan nilai produksi dianalisis dengan menggunakan fungsi produksi Cobb-Douglas, kemudian ditransformasikan dalam bentuk logaritma natural. Rumus yang digunakan adalah: $\mathrm{Y}=\mathrm{a}+\mathrm{a}_{1} \mathrm{X} 1+\mathrm{a}_{2} \mathrm{X} 2+\mathrm{e}$

Dimana Y merupakan kenaikan nilai produksi ternak, x1 adalah nilai penggunaan pakan hijauan, x2 adalah nilai penggunaan obat dan vitamin. an merupakan koefisien regresi dan e adalah error. Variabel Y dan x dinyatakan dalan satuan rupiah per tahun.

b. Efisiensi ekonomis dihitung dengan menggunakan perbandingan antara Nilai Produk Marginal dengan nilai Biaya Korbanan Marginal. Adapun rumusnya adalah sebagai berikut:

$$
\text { Ep }=\text { an } \frac{N P M}{B K M} .
$$

Jika nilai Ep > 1 maka penggunaan input belum efisien, dan jika nilai Ep < maka penggunaan input tidak efisien lagi

\section{HASIL DAN PEMBAHASAN}

\section{Kenaikan Nilai Produksi dan Biaya Produksi Usaha Sapi Potong}

Kenaikan nilai produksi merupakan pertambahan nilai ternak selama pemeliharaan satu tahun. Kenaikan nilai ternak ini dapat berupa adanya pedet yang dilahirkan dan pertumbuhan ternak dari pedet menjadi dara maupun pertumbuhan ternak dara menjadi ternak dewasa. Kenaikan nilai produksi ternak dihitung dari nilai ternak pada akhir tahun dikurangi nilai ternak pada akhir tahun termasuk di dalamnya penjualan ternak dikurangi dengan pembelian ternak selama satu tahun produksi. Sementara itu, biaya produksi dihitung berdasarkan biaya yang benarbenar dikeluarkan oleh peternak. Dalam penelitian ini biaya yang benar-benar dikeluarkan peternak dalam usahanya adalah biaya pembelian obat dan vitamin serta biaya yang digunakan untuk pengadaan pakan hijauan.

Berdasarkan hasil analisis terlihat bahwa rata-rata kenaikan nilai produksi ternak per tahun sebesar Rp. 5·350.000,oo. Kenaikan nilai produksi ternak tertinggi adalah sebesar Rp 24.000.000,00 per tahun dan terrendah sebesar Rp 1.500.000,o0 per tahun. Rata-rata biaya pengadaan pakan hijauan oleh peternak adalah sebesar Rp 2.028.487,50. Biaya pengadaan pakan tertinggi sebesar Rp 7.592.000,00 per tahun dan terrendah sebesar Rp 711.750,00 per tahun. Rata-rata biaya pembelian obat dan vitamin sebesar Rp 201.800,00 dengan biaya tertinggi sebesar $\mathrm{Rp}$ 2.675.000,00 dan terrendah $\mathrm{Rp}$ 15.000,o0 per tahun. Hasil selengkapnya tersaji pada tabel 1 .

Tabel 1. Statisik Deskriptif Kenaikan Nilai Ternak dan Biaya Produksi pada Usaha Ternak Sapi Potong di Kabupaten Banjarnegara

\begin{tabular}{lcrr}
\hline \multicolumn{2}{c}{ Kenaikan Nilai Ternak } & $\begin{array}{r}\text { Biaya Pengadaan } \\
\text { Pakan Hijauan }\end{array}$ & $\begin{array}{c}\text { Biaya Pembelian } \\
\text { Obat dan Vitamin }\end{array}$ \\
\hline Rata-rata & $5.350 .000,00$ & $2.028 .487,50$ & $201.800,00$ \\
Minimum & $1.500 .000,00$ & $711.750,00$ & $15.000,00$ \\
Maksimum & $24.000 .000,00$ & $7.592 .000,00$ & $2.675 .000,00$ \\
Standar deviasi & $4.032 .807,38$ & $1.422 .750,91$ & $328.321,10$ \\
\hline
\end{tabular}

Sumber: data primer diolah 2014

\section{Pengaruh biaya input terhadap kenaikan nilai produksi ternak dan efisiensi ekonomis}

Analisis regresi digunakan untuk melihat pengaruh penggunaan biaya faktor produksi atau input pakan hijauan dan obat dan vitamin terhadap kenaikan 
Tabel 2. Hasil Analisi Regresi penggunaan biaya faktor produksi terhadap kenaikan nilai produksi ternak

\begin{tabular}{lrrrrr}
\hline & Coefficients & Standard Error & \multicolumn{1}{c}{ t Stat } & \multicolumn{1}{c}{ P-value } & Ep \\
\hline Intercept & 1,521 & 0,301 & 5,045 & $2,1 \mathrm{E}-06$ & \\
X1 (pakan hijauan) & 0,767 & 0,059 & $12,918^{* * *}$ & $8,3 \mathrm{E}-23$ & 2,024 \\
X2 (obatdanvitamin) & 0,069 & 0,035 & 1,9705 & 0,05165 & 1,832 \\
R Square $=0,760$ & & F Hit $=153,991$ & & F Sig. & $7,9 \mathrm{E}-31$ \\
\hline
\end{tabular}

Sumber : Data Primer Diolah 2014

Keterangan : Ep : Efisiensi ekonomi; ${ }^{* * *}$ nyata pada tingkat kepercayaan $99 \%$

nilai produksi ternak dan hasil selengkapnya tersaji pada tabel 2. Hasil analisis menunjukkan nilai $\mathrm{R}^{2}$ sebesar 0,760. Besaran nilai $\mathrm{R}^{2}$ merupakan koefisien determinasi yang menggambarkan ketepatan model yang digunakan. Nilai ini menunjukkan bahwa 76 persen variasi dari kenaikan nilai produksi ternak sapi potong dapat dijelaskan oleh variabel penjelas yaitu biaya hijauan dan biaya obat dan vitamin. Sedangkan sisa 24 persen dipengaruhi oleh faktor lain diluar model analisis yang digunakan baik itu dari aspek sosial ataupun aspek ekonomi yang terlibat didalam kegiatan usaha sapi potong tersebut. Dengan nilai F hitung sebesar 153,991 dan signifikan pada tingkat kepercayaan 99 persen menggambarkan bahwa secara bersama-sama variabel penjelas berpengaruh terhadap kenaikan nilai produksi ternak sapi potong.

Pengaruh penggunaan biaya input pakan hijauan dan input obat dan vitamin terhadap kenaikan nilai produksi ternak sapi potong dapat dilihat nilai koefisien faktor produksi pada tabel 2. Hasil analisis menunjukkan bahwa penggunaan pakan hijauan memiliki koefisien sebesar 0,767 signifikan pada tingkat kesalahan 1 persen. Nilai koefisien tersebut menggambarkan bahwa setiap peningkatan biaya pakan hijauan sebesar 10 persen akan memberikan kenaikan nilai ternak sebesar 7,67 persen. Artinya, peternak masih memungkinkan untuk mendapatkan kenaikan nilai ternak dengan menambah penggunaan pakan. Dengan meningkatkan biaya hijauan maka produksi akan meningkat dan mampu menutupi biaya produksi yang telah dikeluarkan. Hal tersebut sesuai dengan pandangan Hanafie (2010), yang menyatakan bahwa bertambahnya biaya diperlukan untuk menambah produksi. Selain itu, hasil ini sesuai dengan hasil analisis efisiensi yang menunjukkan nilai 2,024. Yang berarti secara ekonomi, penggunaan pakan hijauan belum efisien karena nilainya lebih besar dari satu. Diduga kualitas pakan yang beragam, menyebabkan pemberian pakan oleh peternak menjadi belum efisien. Supratman dan Iwan (2001), bahwa pertambahan berat badan yang maksimal akan bisa dicapai bila pakan yang diberikan mencukupi baik kualitas maupun kuantitasnya. Hasil ini juga sejalan dengan temuan Jones (2000), Trestini (2006), Krasachat (2007), dan Sidauruk (2010).

Pada penggunaan biaya input obat dan vitamin, analisis menunjukkan bahwa biaya input ini tidak mempengaruhi kenaikan nilai produksi ternak sapi potong. Hal ini dimungkinkan karena peternak menganggap bahwa obat dan vitamin bukan faktor produksi utama dalam usaha pemeliharaan sapi potong dan hanya faktor produksi pendukung. Hal tersebut menyebabkan kecilnya penggunaan dan biaya obat dan vitamin pada usaha ternak sapi potong di Kabupaten Banjarnegara. Hal ini sesuai dengan analisis efisiensi ekonomi, yang menunjukkan bahwa penggunaan biaya obat dan vitamin belum efisien (bernilai 1,83). Peternak asih memungkinkan untuk menambah pemberian obat dan vitamin guna memberi kenaikan nilai produk ternak yang lebih besar. Pemberian obat dan vitamin memang tidak untuk menaikkan berat badan secara langsung, melainkan untuk pencegahan, penyembuhan dan pemberantasan penyakit yang dapat mempengaruhi produksi. Kondisi ternak yang sehat, kenaikan berat dan produksi telur diharapkan dapat tercapai dengan optimal (Dorland, 2002).

\section{KESIMPULAN}

Biaya pakan hijauan yang dikeluarkan oleh peternak berpengaruh positif terhadap kenaikan nilai produksi ternak sapi potong. Penggunaan biaya pengadaan hijauan pakan ternak dan biaya obat dan vaksin belum efisien. Kenaikan nilai produksi ternak sapi potong di Kabupaten Banjarnegara dapat ditingkatkan dengan memperbaiki efisiensi penggunaan biaya pakan hijauan dan biaya obat dan vitamin guna mendukung kesehatan ternak sehingga kenaikan nilai ternak dapat tercapai secara optimal.

\section{DAFTAR PUSTAKA}

Badan Pusat Statistik. 2013. Banjarnegara Dalam Angka 2013. BPS Kabupaten Banjarnegara.

Dorland W. A. N. 2002. Kamus Kedokteran Dorland. Terjemahan Huriawati Hartanto. Edisi pertama, Jakarta : EGC. Hal : 1815.

Hanafie, R. 2010. Pengantar Ekonomi Pertanian. C.V. Andi Offset, Yogyakarta.

Jones R. 2000. Costs, Distribution of Costs, and Factors Influencing Profitability in Cow-Calf 
Production. Kansas State University.

Kalangi, L.S. 20014. Analisis Efisiensi Ekonomi Usaha Perkembangbiakan Ternak Sapi Potong Rakyat di Propinsi Jawa Timur. Disertasi.Sekolah Pasca Sarjana. Institut Pertanian Bogor. Bogor.

Krasachat W. 2007. Economic Efficiency of Feedlot Cattle Farms in Thailand. Conference on International Agricultural Research for Development. Tropentag University of KasselWitzenhausen and University of Gottingen, October 9-11, 2007

Sidauruk R, Cyrilla L, Atmakusuma J. 2010. Analisis Efisiensi Pola Usaha Sapi Potong di Bekasi Jawa Barat (Kasus di PT Lembu Jantan Perkasa). Media Peternkan, 24(1) : 128-135
Supratman dan Iwan. 2001. Manajemen Pakan Sapi Potong. Pelatihan Wirabisnis Feedlot Sapi Potong Fakultas Peternakan UNPAD, Bandung

Trestini S. 2006. Technical Efficiency of Italian Beef Cattle Production Under a Heteroscedastic Non- Neutral Production Frontier Approach. Conference Paper, Presented at the 10th Joint Conference on Food, Agriculture and the Environment, August 27-30. Duluth, Minnesota Tumewu, J.M, Panelewen, V.V.J, Mirah, A.D.P. 2014. Analisis Usaha Tani Terpadu Sapi Potong dan Padi Sawah Kelompok Tani "Keong Mas" Kecamatan Sangkup, Kabupaten Bolaang Mongondow Utara. Journal Zootek. Vol. 34 No.2:1-9 (Juli 2014). 